\title{
PENGARUH KEADILAN ORGANISASI, BUDAYA ORGANISASI, DAN PEMBERDAYAAN KARYAWAN TERHADAP KOMITMEN ORGANISASIONAL KARYAWAN
}

\author{
Indra Dwi Isnanto 1 \\ I Gusti Ayu Manuati Dewi ${ }^{2}$ \\ ${ }^{1,2}$ Fakultas Ekonomi dan Bisnis Universitas Udayana (Unud), Bali, Indonesia \\ email: indraisnato414@gmail.com
}

\begin{abstract}
ABSTRAK
Penelitan ini bertujan untuk menguji pengaruh keadilan organisasi, budaya organisasi, dan pemberdayaan karyawan terhadap komitmen organisasional. Lokasi penelitian adalah PT. Bank Tabungan Negara (Persero), Tbk Cabang Denpasar. Sampel sebanyak 70 orang menggunakan teknik sampel jenuh atau sensus. Pengumpulan data dilakukan melalui penyebaran kuesioner dengan pengukur variabel menggunakan Skala Likert 5 poin. Teknik analisis yang digunakan adalah analisis regresi linier berganda. Hasil analisis menunjukkan bahwa keadilan organisasi, budaya organisasi, dan pemberdayaan karyawan berpengaruh positif dan signifikan terhadap komitmen organisasional. Pihak manajemen PT. Bank Tabungan Negara (Persero), Tbk Cabang Denpasar disarankan untuk meningkatkan keadilan organisasi, budaya organisasi, dan pemberdayaan karyawan, sehingga karyawan akan memiliki komitmen yang tinggi terhadap organisasinya.

Kata kunci : keadilan organisasi, budaya organisasi, pemberdayaan karyawan, komitmen organisasional
\end{abstract}

\begin{abstract}
This research is intends to examine organization justice, organization culture, and employee empowerment to organizational commitment. This research location at PT. Bank Tabungan Negara (Persero), Tbk Denpasar Branch Office. Samples taken of 70 persons using purposive saturated or census sampling technique. The data collection is done by distributing questionnaires 5-point Likert scale. Analysis technique used is multiple linear regression analysis. The analysis showed that organization justice, organization culture, and employee empowerment positive significant effect on organizational commitment. PT. Bank Tabungan Negara (Persero), Tbk Denpasar Branch Office it's recommended to improve organization justice, organization culture, and employee empowerment variables to increase organizational commitment.

Keywords: organization justice, organization culture, and employe empowerment, organizational commitment
\end{abstract}




\section{PENDAHULUAN}

Keberhasilan pihak manajemen dalam mengelola usaha dan bisnis sangat ditentukan oleh kemampuan dalam melaksanakan kegiatan operasionalnya. Pelaku bisnis tentu memiliki strategi yang berbeda-beda dalam mencapai tujuan perusahaan. Hal tersebut disebabkan oleh persaingan dunia bisnis yang semakin ketat dan kompetitif, menuntut perusahaan agar responsif terhadap perubahan yang terjadi. Tintri (2005) menyatakan bahwa manusia merupakan sumber daya yang paling penting dan menentukan arah perubahan organisasi.

Strategi bisnis yang mampu mengelola dan meningkatkan kualitas sumber daya manusia diperlukan untuk merespon perubahan yang dinamis. Melalui peningkatan pengetahuan, keterampilan, dan kemampuan diharapkan sumber daya manusia yang terlibat dalam proses atau kegiatan organisasi merupakan sumber daya manusia berbasis kompetensi dengan keterampilan dan keahlian yang mumpuni (Anatan \& Ellitan, 2007).

Perkembangan perekonomian di Indonesia tidak terlepas dari peran lembaga keuangan. PT Bank Tabungan Negara (Persero), Tbk merupakan perusahaan yang bergerak di bidang perbankan mulai dari pembiayaan kredit rumah, asuransi, tabungan dan sebagainya. Saat ini banyak bermunculan bank-bank swasta yang juga menawarkan berbagai pilihan produk ataupun layanan perbankan yang sama dan tidak kalah bersaing dengan apa yang ditawarkan oleh bank-bank milik pemerintah. Kemampuan mengelola sumber daya manusia yang baik harus dimiliki PT. Bank Tabungan Negara (Persero), Tbk Cabang Denpasar agar nantinya sumber daya manusia pada internal perusahaan mampu berkontribusi dalam proses mencapai tujuan perusahaan yang salah satunya yakni keunggulan kompetitif.

Menurut Ardana dkk. (2012:3) sumber daya manusia merupakan komponen utama yang harus melekat pada suatu organisasi. Peran sumber daya manusia sangat menentukan keberhasilan suatu organisasi. Oleh karena itu, organisasi perlu memperhatikan beberapa sasaran dalam manajemen sumber daya manusia diantaranya penerapan keadilan organisasi, budaya organisasi, pemberdayaan karyawan, dan komitmen organisasional.(Edelstein \& Molinski, 2012). Para ahli pada umumnya memberikan pandangan yang beragam mengenai komitmen organisasional. komitmen organisasional merupakan keyakinan yang menjadi pengikat karyawan dalam suatu organisasi tempatnya bekerja, yang dapat ditunjukkan dengan adanya loyalitas, keterlibatan dalam pekerjaan dan identifikasi terhadap nilai serta tujuan organisasi.

Komitmen organisasional merupakan sikap penerimaan dan keyakinan yang kuat terhadap nilai-nilai dan tujuan sebuah organisasi begitu juga dengan adanya dorongan yang kuat untuk mempertahankan keanggotaan dalam organisasi demi tercapainya tujuan organisasi (Abadi \& Chegini, 2013). Komitmen organisasional penting untuk diteliti, karena komitmen tersebut mampu mempengaruhi keberhasilan organisasi jangka panjang.

Astuti (2013) menyatakan komitmen organisasional merupakan salah satu faktor yang berpengaruh terhadap keberhasilan organisasi dalam menghadapi lingkungan yang kompleks. Semakin karyawan serius, loyal, dan memiliki kasih 
sayang tehadap organisasi akan mampu mengejar tujuan organisasi.(Farzin \& Jirdehi, 2013)

Penelitian awal yang dilakukan dengan mendistribusikan kuesioner kepada 6 orang karyawan diperoleh hasil yang menyatakan karyawan tidak merasa dirugikan jika harus meninggalkan perusahaan dan mudah mendapatkan pekerjaan seperti yang sedang diperoleh saat ini. Hasil Kuesioner yang telah terkumpul dari beberapa responden yang sedang menjabat sebagai Senior Staff (Acc \& Reporting Staff), Senior Staff (Internal Control), Data Entry, Verifying terungkap lima dari enam responden tersebut mengungkapkan tidak mengalami kerugian jika meninggalkan organisasi dan siap meninggalkan pekerjaan dengan jabatan yang sedang di emban saat ini jika ada pekerjaan yang lebih baik. Komitmen organisasional karyawan sangat penting untuk diteliti, karena mampu mempengaruhi keberhasilan suatu organisasi dalam jangka panjang. Oleh karena itu, perusahaan harus mampu mempertahankan sumber daya manusia yang sudah ada dengan memenuhi kebutuhan mereka agar tercipta komitmen yang tinggi terhadap perusahaan.

Keadilan organisasi merupakan salah satu variabel yang mempengaruhi komitmen organisasional (Diputri \& Rahyuda, 2016). Gibson et al. (2012) mendefinisikan keadilan organisasi sebagai suatu tingkat dimana seorang individu merasa diperlakukan sama di organisasi tempat dia bekerja. Yavuz (2010) menyatakan dengan memperkuat keadilan organisasi adalah salah satu langkah penting dalam meningkatkan komitmen organisasional. Apabila karyawan diperlakukan secara adil, akan mampu meningkatkan komitmen mereka untuk tetap menjadi bagian dari organisasi. Dewi \& Suana (2016) menyatakan keadilan organisasi sebagai suatu konsep keseimbangan dalam memperlakukan karyawan diharapkan mampu diterapkan oleh organisasi dengan tujuan memicu tumbuhnya suatu rasa berkomitmen dalam diri karyawan.

Keunggulan suatu organisasi juga ditentukan oleh budaya organisasi yang dimiliki oleh organisasi tersebut. Budaya organisasi merupakan hal esensial bagi suatu organisasi karena akan selalu berhubungan dengan kehidupan yang ada pada organisasi. Berkaitan dengan budaya organisasi akan menunjukkan bagaimana kemauan seorang karyawan dalam melanjutkan pekerjaannya, setia kepada organisasinya, mengerahkan usaha ekstra untuk pencapaian tujuan, dan pengidentifikasian karyawan dalam memenuhi tujuan organisasi (Haq et al., 2014)

Budaya organisasi menurut Robbins \& Judge (2008) adalah Sistem makna bersama terhadap nilai-nilai primer yang dianut bersama dan dihargai organisasi, dan berfungsi menciptakan pembedaan yang jelas antara satu organisasi dengan organisasi lainnya, menciptakan rasa identitas bagi para anggota organisasi, mempermudah timbulnya komitmen kolektif terhadap organisasi, meningkatkan kemantapan sistem sosial, serta menciptakan mekanisme pembuat makna dan kendali yang memandu membentuk sikap dan perilaku para anggota organisasi. Perilaku manusia dan dinamika budaya diperlukan sebagai pedoman untuk mempelajari bagaimana karyawan berkomitmen terhadap organisasi.

Pemberdayaan karyawan menjadi isu yang berkaitan dengan komitmen organisasional. Elnaga \& Imran (2014) menyatakan bahwa pemberdayaan 
karyawan merupakan upaya melibatkan karyawan untuk bertanggungjawab didalam proses kerjanya. Suhermin (2012) menyatakan bahwa pemberdayaan karyawan berpengaruh langsung terhadap komitmen organisasional. Ongori (2008) melihat bahwa adanya persaingan yang semakin ketat antar perusahaan mendorong organisasi untuk membuat kebijakan yang mendukung pemberdayaan karyawan. Pemberdayaan terhadap karyawan menjadi salah satu kebutuhan sebuah instansi demi mewujudkan tujuan perusahaan. Tujuan yang ingin dicapai dalam penelitian ini adalah mengetahui pengaruh keadilan organisasi terhadap komitmen organisasional, budaya organisasi terhadap komitmen organisasional, dan pemberdayaan karyawan terhadap komitmen organisasional PT. Bank Tabungan Negara (Persero), Tbk Cabang Denpasar.

Teori Sisi Taruhan (The Side-bets Theory) merupakan sebuah teori yang menjelaskan korelasi antara variabel karyawan dan variabel organisasi yang didasarkan atas asas perilaku pertukaran ekonomi. Adanya asumsi bahwa investasi yang dibuat seorang karyawan didalam oganisasinya adalah berkomitmen berdasarkan sisi taruhan (Side-bets). Karyawan akan memiliki komitmen dan mampu bertahan lebih lama di dalam perusahaan jika kebutuhan karyawan terpenuhi terkait keadilan organisasi, budaya organisasi, dan bagaimana pemberdayaan terhadap karyawan tersebut di dalam organisasi tempatnya bekerja. Sisi Taruhan (Side-bets) mengacu pada akumulasi investasi yang dihargai oleh seorang karyawan. Akumulasi investasi didasarkan atas manfaat dan kerugian yang akan diterima untuk tetap tinggal atau meninggalkan organisasi yang terkait seperti pensiun, senioritas, status sosial, dan akses ke jaringan sosial yang mengikat (Shurbagi \& Zahari, 2013). Investasi tersebut akan mengurangi daya tarik alternatif pekerjaan di tempat lain. Pertimbangan biaya dan manfaat mendorong sesorang karyawan tetap berkomitmen terhadap organisasi.

Sidartha \& Margaretha menyatakan bahwa komitmen organisasional pada sebuah perusahaan merupakan salah satu jaminan untuk menjaga eksistensi perusahaan tersebut. Tujuan organisasi dapat tercapai apabila karyawan memiliki komitmen terhadap organisasinya, karena karyawan yang berkomitmen akan bersedia dan berusaha agar tujuan organisasi tercapai (Nagar, 2012). Ivancevich \& Matteson (2008) menyatakan komitmen organisasional merupakan rasa identifikasi, keterlibatan, dan kesetiaan yang diekspresikan oleh karyawan terhadap organisasinya.

Yukl (2006) menyatakan komitmen organisasional adalah persetujuan karyawan terhadap keputusan atau permintaan organisasi dan melakukan usaha yang serius untuk menjalankan permintaan atau menerapkan keputusan sejalan dengan kepentingan organisasi. Dessler (2003) menyatakan bahwa komitmen organisasional adalah identifikasi karyawan terhadap persetujuan untuk mencapai misi organisasi. Komitmen organisasional karyawan dapat ditunjukan dalam sikap penerimaan, keyakinan kuat dari tujuan organisasi dan adanya dorongan untuk menjadi bagian organisasi dalam proses mencapai tujuan.

Priansa (2016) menyatakan komitmen organisasional merupakan konsep manajemen yang menempatkan sumber daya manusia sebagai figure sentral bagi organisasi. Tanpa komitmen organisasional, sukar mendapatkan partisipasi aktif dan mendalam dari sumber daya manusia. Oleh karena itu, komitmen 
organisasional harus dipelihara agar tetap tumbuh di sanubari Sumber daya manusia.

Fernandes \& Awamleh (2006) menyatakan bahwa keadilan organisasi memiliki peran yang penting terkait imbalan yang akan diberikan secara adil sesuai bidangnya yang pantas mereka dapatkan di perusahaan. Keadilan organisasi merupakan faktor penting, karena reward yang mereka dapatkan di perusahaan itu sesuai dengan kinerja para karyawan.

Farzin \& Jirdehi (2013) menyatakan bahwa keadilan organisasi sebagai suatu kesetaraan ditempat kerja dan rasa pribadi dari upah dan tunjangan yang diterima. Keadilan organisasi merupakan suatu konsep keseimbangan yang diharapkan mampu diterapkan oleh organisasi dalam memperlakukan karyawan dengan tujuan memicu tumbuhnya rasa berkomitmen dalam diri karyawan (Sutrisna \& Rahyuda, 2014).

Utami (2009) Komitmen organisasional akan diperoleh apabila organisasi mampu memenuhi harapan karyawan yang berkaitan dengan imbalan atau gaji dan hak-hak lainnya yang diperoleh oleh karyawan. Menurut Ogut et al. (2013) ketika karyawan telah merasa bahwa manajer pada suatu organisasi berperilaku adil kepada mereka, kerjasama antara atasan dan bawahan akan lebih mudah dan bawahan akan mendukung keputusan yang dibuat oleh atasan.

Darodjat (2015) menyatakan bahwa budaya organisasi merupakan sekumpulan karakteristik kunci yang dijunjung tinggi oleh organisasi tetapi memberikan kepuasan kerja dalam kinerja organisasi dan respon efektif terhadap lingkungan kerja. Budaya organisasi mampu mendukung perusahaan untuk mempermudah mencapai tujuan secara efektif dan efisien. Budaya organisasi memiliki pengaruh besar pada keberhasilan dan hidup mati suatu organisasi. Suatu budaya dalam organisasi tidak muncul begitu saja. Bila sudah terbentuk mantap, budaya tidak akan menghilang begitu saja. Kebiasaan, tradisi, dan caracara umum dalam mengerjakan sesuatu yang sudah ada dalam suatu organisasi berkaitan erat dengan apa yang telah dilakukan sebelumnya dan dengan tingkat keberhasilan organisasi tersebut dengan berbagai upaya yang dilakukan.

Greenberg dan Baron, dalam Darodjat (2015) menyatakan bahwa budaya organisasi sebagai kerangka kerja kognitif yang terdiri dari sikap, nilai-nilai, norma perilaku, dan harapan yang diterima bersama oleh anggota organisasi. Wirawan (2007:10) menyatakan budaya organisasi sebagai norma, nilai-nilai, asumsi, kepercayaan, filsafat, kebiasaan organisasi, dan sebagainya. Selain itu, budaya memberikan pedoman bagi karyawan bagaimana dia mempersepsikan karakteristik budaya suatu organisasi, nilai yang dibutuhkan karyawan dalam bekerja, berinteraksi dengan kelompoknya, sistem, dan administrasi, serta berinteraksi dengan atasan. Luthans (2006) melihat budaya organisasi memberikan arah dan memperkuat standar perilaku untuk mengendalikan perilaku organisasi agar melaksanakan tugas dan tanggung jawab mereka secara efektif dan efisien untuk mencapai tujuan dan sasaran organisasi yang telah disepakati bersama.

Pemberdayaan merupakan pemberian tanggung jawab dan wewenang kepada pegawai untuk mengemban pekerjaanya serta mengambil keputusannya. Khan (2007) menyatakan bahwa pemberdayaan merupakan hubungan antar 
individu yang berkelanjutan untuk membangun kepercayaan antara pegawai dan manajemen organisasi.

Stewart, dalam (Priansa, 2016) mengatakan bahwa pemberdayaan berarti kekuasaan yang merupakan kemampuan untuk mengusahakan sesuatu itu terjadi ataupun tidak sama sekali. Brown (2004) mengatakan bahwa pemberdayaan erat hubungannya dengan profesionalisme yang pada awalnya selalu dimiliki oleh individu. Pemberdayaan karyawan dapat pula dikatakan sebagai suatu upaya melibatkan karyawan untuk bertanggung jawab didalam proses kerjanya (Elnaga \& Imran, 2014)

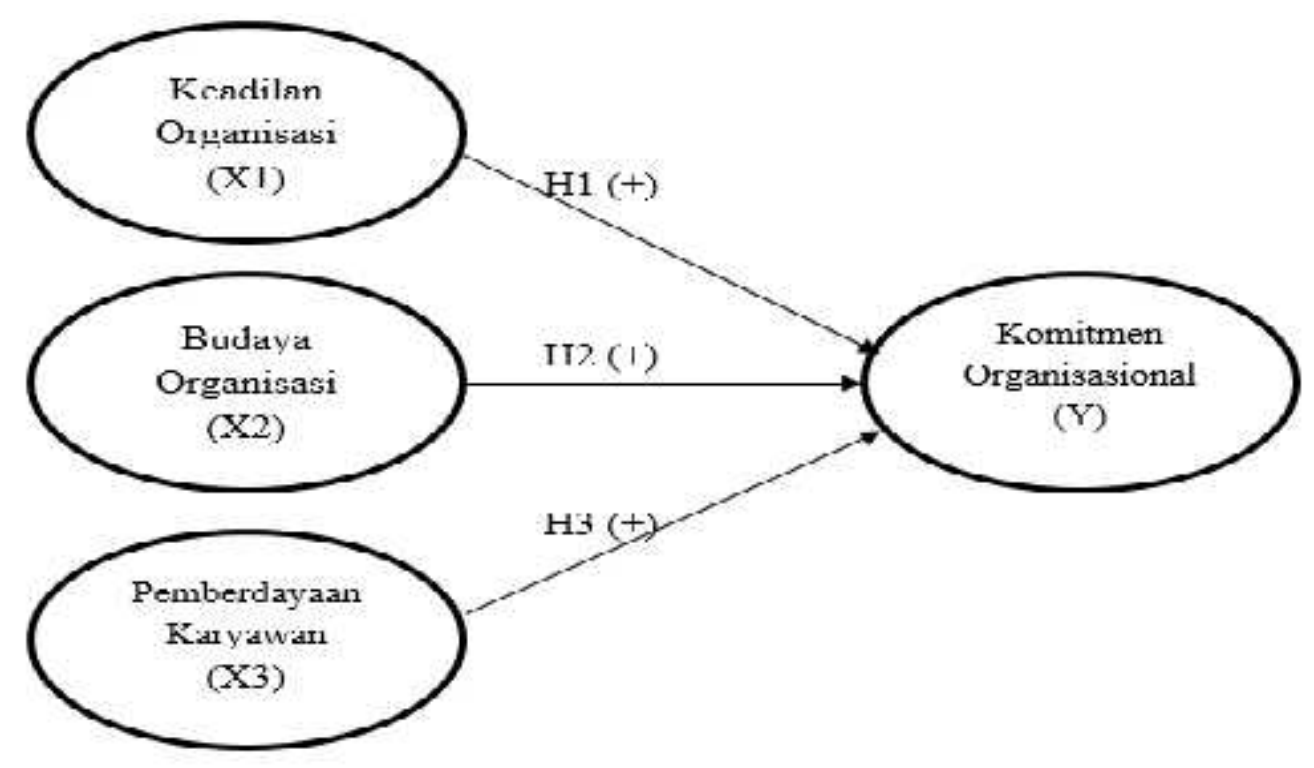

Gambar 1. Model Kerangka Konseptual

Sumber : Data diolah, 2019

Dehkordi \& Yektayar (2013) yang menemukan bahwa keadilan organisasi berpengaruh positif dan signifikan terhadap komitmen organisasional. Akanbi et al. (2013) dalam penelitiannya yang dilakukan di perusahaan Nestle Nigeria dengan jumlah sampel sebanyak 215 orang karyawan menemukan hasil terdapat pengaruh yang signifikan antara keadilan distributif terhadap komitmen organisasional karyawan. Demirel \& Yucel (2013) mengemukakan bahwa keadilan distributif, keadilan prosedural dan keadilan interaksional memiliki hubungan positif terhadap komitmen afektif.

Ravangard \& Ansarizade (2013) menyatakan keadilan organisasi merupakan alat motivasi dan mempengaruhi komitmen organisasional. Schuler \& Jackson (1997:78) mengelola karyawan dengan adil pada prinsipnya ialah menyeimbangkan hak dan kewajiban manajemen serta karyawan, dengan demikian karyawan akan patuh terhadap organisasi jika kebijakan, prosedur, dan pelaksanaan sudah diterapkan secara adil bagi seluruh karyawan.

$\mathrm{H}_{1}$ : Keadilan organisasi berpengaruh positif terhadap komitmen organisasional. 
Renaud (2012) memperoleh hasil dari penelitiannya bahwa persepsi positif dari budaya organisasi akan meningkatkan komitmen karyawan. Budaya organisasi mampu mempengaruhi komitmen organisasional. Organisasi harus mampu menilai budaya mereka sebelum mencoba mengubah atau memperbaharui budaya tersebut. Apabila persepsi karyawan terhadap budaya organisasi tempat mereka bekerja cukup kondusif dan menyenangkan sebagai tempat bekerja akan berakibat pada kenyamanan yang dirasakan dan tumbuh komitmen terhadap organisasi.

Kumar et al. (2012) memperoleh hasil dari penelitian yang dilakukan jika budaya organisasi dan komitmen organisasional memiliki pengaruh yang signifikan terhadap niat karyawan untuk meninggalkan organisasi. Bakhshi et al. (2009) menyatakan bahwa keadilan distributif dan keadilan prosedural ditemukan secara signifikan berhubungan dengan komitmen organisasional. Marissa (2010) menyatakan bahwa dari keempat dimensi keadilan terbukti bahwa keadilan distributif, prosedural dan informasional memiliki pengaruh yang signifikan terhadap komitmen organisasional.

$\mathrm{H}_{2}$ : Budaya organisasi berpengaruh positif terhadap komitmen organisasional.

Pemberdayaan karyawan berpengaruh positif terhadap komitmen organisasional. Karyawan yang mendapatkan pemberdayaan pada praktek manajemennya membuktikan bahwa semakin kuat tingkat kepuasan kerja dan komitmen organisasional (Humborstad \& Perry, 2011). Karim \& Rehman (2012) memperoleh hasil bahwa pemberdayaan yang diberikan untuk karyawan akan bahkan menyatakan bahwa pemberdayaan yang diberikan untuk karyawan akan meningkatkan komitmen organisasional karyawan pada organisasi tersebut.

Suhermin (2012) dalam penelitiannya menyatakan bahwa pemberdayaan memberikan pengaruh langsung terhadap komitmen organisasional. Hal ini memiliki makna bahwa semakin baik tingkat pemberdayaan yang dilakukan organisasi terhadap karyawannya maka akan memberikan peningkatan komitmen organisasional, begitu juga sebaliknya.

Pratiwi (2012) dalam penelitiannya menyatakan bahwa ada pengaruh yang searah antara pemberdayaan dengan komitmen organisasional, dengan demikian dapat dikatakan bahwa melalui pemberdayaan karyawan akan mempunyai kontrol secara personal tentang bagaimana melakukan pekerjaan dan memiliki keyakinan akan kemampuan yang dimiliki dengan hasil dalam bentuk komitmen organisasional. Berdasarkan berbagai hasil penelitian tersebut maka dapat dirumuskan hipotesis sebagai berikut.

$\mathrm{H}_{3}$ :Pemberdayaan Karyawan berpengaruh positif terhadap komitmen organisasional

\section{METODE PENELITIAN}

Penelitian ini memiliki sifat asosiatif yang bertujuan untuk mengetahui pengaruh atau hubungan antara dua variabel atau lebih. Metode penelitiannya tergolong penelitian kuantitatif yang meneliti pada sampel atau populasi tertentu. Pendekatan kuantitatif merupakan metode penelitian yang berlandaskan pada filsafat positivism, digunakan pada populasi atau sampel tertentu. Teknik 
pengambilan sampel menggunakan teknik sampel jenuh, pengumpulan data menggunakan instrumen penelitian, analisis data bersifat kuantitatif dengan tujuan untuk menguji hipotesis yang telah ditetapkan. Populasi dalam penelitian ini adalah seluruh karyawan (PT) Bank Tabungan Negara (Persero), Tbk Cabang Denpasar berjumlah 70 karyawan.

Tabel 1.

Jumlah Karyawan PT. Bank Tabungan Negara (Persero) Cabang Denpasar

\begin{tabular}{clc}
\hline No & \multicolumn{1}{c}{ Devisi } & Jumlah Karyawan (Orang) \\
\hline 1 & Mortgage and Consumer Lending Unit & 13 \\
2 & Commercial Small and Medium Unit & 6 \\
3 & Branch Funding Sales & 19 \\
4 & Priority Banking Branch & 4 \\
5 & Operation Unit & 11 \\
6 & Credit Admin Unit & 7 \\
7 & Acounting Control Unit & 3 \\
8 & Collection Branch Coordinator & 7 \\
& Jumlah & $\mathbf{7 0}$ \\
\hline
\end{tabular}

Sumber : Data diolah, 2019

Teknik Pengumpulan data dilakukan melalui instrumen penelitian berupa kuesioner dengan metode angket, penyebaran kuesioner secara langsung kepada responden untuk dijawab sendiri. Kuesioner yang digunakan terdiri atas pertanyaan yang dibuat berdasarkan masing-masing variabel, yaitu variabel keadilan organisasi, budaya organisasi, pemberdayaan karyawan terhadap komitmen organisasional. Hasil jawaban kemudian diukur dengan menggunakan skala likert. Adapun variabel bebas dalam penelitian ini adalah keadilan organisasi $\left(\mathrm{X}_{1}\right)$, budaya organisasi $\left(\mathrm{X}_{2}\right)$, pemberdayaan karyawan $\left(\mathrm{X}_{3}\right)$ sedangkan variabel terikat adalah komitmen organisasional (Y).

Teknik analisis data yang digunakan dalam penelitian ini adalah regresi linier berganda. Model regresi linier berganda dalam penelitian ini digunakan untuk mengetahui pengaruh keadilan organisasi, budaya organisasi, pemberdayaan karyawan terhadap komitmen organisasional. Dalam pengolahan data menggunakan bantuan SPSS. Model regresi linier berganda yang dimaksud, dapat dirumuskan sebagai berikut:

$\mathrm{Y}=\alpha+\beta 1 \mathrm{X}_{1}+\beta 2 \mathrm{X}_{2}+\beta 3 \mathrm{X}_{3}+\mu \mathrm{i}$

Variabel pengganggu $(\mu)$ yang mewakili faktor lain berpengaruh terhadap Y namun tidak dimasukkan dalam model. (a) merupakan bilangan konstanta, (Y) merupakan variabel terikat yaitu komitmen organisasional, $\left(\mathrm{X}_{1}\right)$ merupakan variabel bebas pertama yaitu keadilan organisasi, $\left(\mathrm{X}_{2}\right)$ merupakan variabel bebas kedua yaitu budaya organisasi, $\left(\mathrm{X}_{3}\right)$ merupakan variabel bebas ketiga yaitu pemberdayaan karyawan, $\left(\beta_{1}, \beta_{2}, \beta_{3}\right)$ Koefisien regresi variabel $X_{1}, X_{2}, X_{3}$.

Uji $\mathrm{F}$ digunakan untuk mengetahui kelayakan model regresi linier berganda sebagai alat analisis yang menguji pengaruh keadilan organisasi, budaya organisasi, pemberdayaan karyawan terhadap komitmen organisasional. Caranya dengan membandingkan nilai Fhitung lebih besar dari nilai Ftabel maka hipotesis 0 ditolak dan hipotesis alternatif diterima. Uji $\mathrm{F}$ dapat diketahui dengan melihat nilai signifikasi pada Tabel anova. 
Koefisien determinasi $\left(\mathrm{R}^{2}\right)$ digunakan untuk mengukur seberapa jauh kemampuan model dalam menerangkan variasi dari variabel bebas. Nilai koefisien determinasi adalah antara nol dan satu. Nilai $\mathrm{R}^{2}$ kecil jika kemampuan variabel bebas menjelaskan variabel terikat terbatas. Nilai yang hampir mendekati satu berarti variabel-variabel bebas memberikan informasi yang dibutuhkan untuk memprediksi variasi variabel terikat.

Uji statistik t pada dasarnya menunjukkan seberapa jauh pengaruh satu variabel bebas secara parsial dalam menerangkan variasi variabel terikat $\mathrm{H}_{1}$ ditolak berarti variabel bebas keadilan organisasi, budaya organisasi, pemberdayaan karyawan tidak berpengaruh positif terhadap variabel terikat yaitu komitmen organisasional. Sebaliknya jika $\mathrm{H}_{1}$ diterima berarti variabel bebas yaitu keadilan organisasi, budaya organisasi, pemberdayaan karyawan berpengaruh positif terhadap variabel terikat yaitu komitmen organisasional

\section{HASIL DAN PEMBAHASAN}

Pendistibusian kuesioner dilakukan di PT. Bank Tabugan Negara (Persero), Tbk Cabang Denpasar dengan responden berjumlah 70 orang. Kuesioner yang kembali terkumpul sebanyak 70 lembar, sehingga tingkat responden yang mengembalikan kuesioner adalah sebesar (100\%).

Pada bagian ini karakteristik responden yang digambarkan menyangkut empat aspek yaitu, usia, jenis kelamin, masa kerja, dan tingkat pendidikan terakhir. Berdasarkan Tabel 2, responden atau karyawan pada PT. Bank Tabungan Negara (Persero) Cabang Denpasar sebagian besar berumur antara 25 - 30 tahun berjumlah 44 orang dengan jumlah $(62,85 \%)$. Karyawan di dominasi usia 25-30 tahun dikarenakan usia tersebut merupakan usia produktif.

Faktor usia menjadi penunjang perusahaan dalam menghasilkan jasa yang berkualitas. Jenis kelamin karyawan laki-laki lebih mendominasi dibandingkan karyawan perempuan yaitu 42 laki-laki dan 28 perempuan. Karyawan laki-laki mendominasi karena banyaknya bidang pekerjaan yang membutuhkan tenaga laki-laki sebagai contoh Credit Admin Unit. Pada posisi kerja tersebut penanggungjawab merupakan karyawan laki-laki karena berkaitan dengan pelayanan pinjaman/kredit kepada nasabah atau debitur.

Masa bekerja menunjukkan karyawan yang bekerja kurang dari 5 tahun lebih banyak berjumlah 46 orang dengan $(65,71 \%)$. Masa bekerja kurang dari 5 tahun dikarenakan perusahaan memberlakukan sistem rotasi untuk meningkatkan fleksibilitas, keterampilan, dan keterlibatan karawan terhadap perusahaan. Data mengenai tingkat pendidikan karyawan yang muncul seluruh karyawan berpendidikan Sarjana. Seluruh karyawan telah memiliki latar belakang pendidikan sarjana karena banyaknya pekerjaan yang membutuhkan skill khusus misalnya Accounting Control Unit dengan penanggung jawab meruapakan lulusan sarjana akuntansi.

Suatu kuesioner umumnya dinyatakan kebenarannya bila memuat pertanyaan yang mengungkapkan data yang diperoleh dari kuesioner itu sendiri. Uji validitas instrumen dilakukan untuk memastikan bahwa butir-butir pertanyaan pada kuesioner sudah valid. Valid menandakan bahwa instrumen tersebut dapat digunakan untuk mengukur apa yang seharusnya diukur. Uji validitas dilakukan 
dengan mengkorelasikan antara skor total. Bila koefisien korelasi dari setiap butir dengan skor total tersebut positif dan nilainya sama atau lebih besar 0,30 ( $\mathrm{r} \geq$ maka instrumen tersebut dikatakan valid). Hasil uji validitas dilakukan menggunakan program SPSS. Hasil pengujian validitas instrumen pada penelitian ini dilakukan dengan melihat nilai pearson correlation. Adapun uji Validitas disajikan pada Tabel 3 .

Berdasarkan Tabel 3. menunjukkan bahwa seluruh indikator pernyataan dalam variabel keadilan organisasi, budaya organisasi, pemberdayaan karyawan, dan komitmen organisasional memiliki pearson correlation yang lebih besar dari 0,3 sehingga seluruh indikator tersebut telah memenuhi syarat validitas data.

Tabel 2.

Karakteristik Responden

\begin{tabular}{|c|c|c|c|}
\hline \multirow{2}{*}{ No. } & \multirow{2}{*}{ Usia } & \multicolumn{2}{|c|}{ Jumlah } \\
\hline & & Orang & Persentase (\%) \\
\hline 1. & $20-25$ & 9 & 12.85 \\
\hline 2. & $26-30$ & 44 & 62.85 \\
\hline 3. & $31-35$ & 10 & 14.30 \\
\hline 4 & Lebih dari 35 & 7 & 10 \\
\hline \multicolumn{2}{|r|}{ Jumlah } & 70 & 100 \\
\hline \multirow[b]{2}{*}{ No. } & \multirow[b]{2}{*}{ Jenis Kelamin } & \multicolumn{2}{|c|}{ Jumlah } \\
\hline & & \multicolumn{2}{|c|}{$\begin{array}{c}\text { Persentase } \\
(\%)\end{array}$} \\
\hline 1. & Laki-laki & 42 & 60 \\
\hline 2. & Perempuan & 28 & 40 \\
\hline \multicolumn{2}{|r|}{ Jumlah } & 70 & 100 \\
\hline \multirow[b]{2}{*}{ No. } & \multirow[b]{2}{*}{ Masa Kerja (Tahun) } & \multicolumn{2}{|c|}{ Jumlah } \\
\hline & & \multicolumn{2}{|c|}{$\begin{array}{c}\text { Persentase } \\
(\%)\end{array}$} \\
\hline 1. & $0-5$ & 46 & 65.71 \\
\hline 2. & $6-10$ & 16 & 22.86 \\
\hline \multirow[t]{2}{*}{3.} & Lebih dari 10 & 8 & 11.43 \\
\hline & Jumlah & 70 & 100 \\
\hline \multirow[b]{2}{*}{ No. } & \multirow[b]{2}{*}{ Tingkat Pendidikan } & \multicolumn{2}{|c|}{ Jumlah } \\
\hline & & Orang & $\begin{array}{c}\text { Persentase } \\
(\%)\end{array}$ \\
\hline 1. & Sarjana & 70 & 100 \\
\hline & Jumlah & 70 & 100 \\
\hline
\end{tabular}

Sumber : Data diolah, 2019

Pada Tabel 4. pengujian reliabilitas dilakukan dengan menggunakan Cronbach's Alpha dari setiap instrumen yang mengukur variabel, instrumen dikatakan reliabel jika seluruh butir-butir pertanyaan dalam instrumen memberikan nilai Cronbach's Alpha lebih dari 0,6. Berdasarkan Uji Reabilitas pada Tabel 4, data yang diolah menunjukkan bahwa keempat instrumen penelitian yaitu variabel keadilan organisasi, budaya organisasi, pemberdayaan karyawan, dan komitmen organisaisonal memiliki koefisien Cronbach'c Alpha lebih besar 
dari 0,60 sehingga pernyataan pada kuesioner tersebut reliabel untuk digunakan melakukan penelitian.

Tabel 3.

Hasil Uji Validitas Instrumen Penelitian

\begin{tabular}{|c|c|c|c|}
\hline Variabel & Indikator & Pearson Correlation & Keterangan \\
\hline \multirow{5}{*}{$\begin{array}{l}\text { Keadilan Organisasi } \\
\text { (X1) }\end{array}$} & $\mathrm{X} 1.1$ & 0,404 & Valid \\
\hline & $\mathrm{X} 1.2$ & 0,467 & Valid \\
\hline & $\mathrm{X} 1.3$ & 0,588 & Valid \\
\hline & $\mathrm{X} 1.4$ & 0,789 & Valid \\
\hline & $\mathrm{X} 1.5$ & 0,563 & Valid \\
\hline \multirow{11}{*}{$\begin{array}{l}\text { Budaya Organisasi } \\
\text { (X2) }\end{array}$} & X1.6 & 0,652 & Valid \\
\hline & $\mathrm{X} 2.1$ & 0,701 & Valid \\
\hline & $\mathrm{X} 2.2$ & 0,491 & Valid \\
\hline & $\mathrm{X} 2.3$ & 0,560 & Valid \\
\hline & $\mathrm{X} 2.4$ & 0,432 & Valid \\
\hline & $\mathrm{X} 2.5$ & 0,510 & Valid \\
\hline & $\mathrm{X} 2.6$ & 0,478 & Valid \\
\hline & $\mathrm{X} 2.7$ & 0,436 & Valid \\
\hline & $\mathrm{X} 2.8$ & 0,363 & Valid \\
\hline & $\mathrm{X} 2.9$ & 0,701 & Valid \\
\hline & $\mathrm{X} 2.10$ & 0,560 & Valid \\
\hline \multirow{7}{*}{$\begin{array}{c}\text { Pemberdayaan } \\
\text { Karyawan } \\
\text { (X3) }\end{array}$} & $\mathrm{X} 2.11$ & 0,498 & Valid \\
\hline & $\mathrm{X} 2.12$ & 0,584 & Valid \\
\hline & $\mathrm{X} 3.1$ & 0,622 & Valid \\
\hline & $\mathrm{X} 3.2$ & 0,582 & Valid \\
\hline & X3.3 & 0,848 & Valid \\
\hline & X 3.4 & 0,733 & Valid \\
\hline & Y.1 & 0,596 & Valid \\
\hline \multirow{8}{*}{$\begin{array}{c}\text { Komitmen } \\
\text { Organisasional (Y) }\end{array}$} & Y.2 & 0,590 & Valid \\
\hline & Y.3 & 0,602 & Valid \\
\hline & Y.4 & 0,572 & Valid \\
\hline & Y.5 & 0,494 & Valid \\
\hline & Y.6 & 0,764 & Valid \\
\hline & Y.7 & 0,462 & Valid \\
\hline & Y.8 & 0,562 & Valid \\
\hline & Y.9 & 0,546 & Valid \\
\hline
\end{tabular}

Sumber : Data diolah, 2019

Tabel 4.

Hasil Uji Reliabilitas

\begin{tabular}{ccc}
\hline Variabel & Cronbadh'sAlpha & Keterangan \\
\hline Keadilan Organisasi (X1) & 0,695 & Reliabel \\
Budaya Organisasi (X2) & 0,706 & Reliabel \\
Pemberdayan Karyawan (X3) & 0,650 & Reliabel \\
Komitmen Organisasional (Y) & 0,657 & Reliabel \\
\hline
\end{tabular}

Sumber: Data diolah, 2019

Pada Tabel 6. budaya organisasi yang sangat baik dengan nilai rata-rata 4,57, dapat diartikan bahwa karyawan menguasai pekerjaan dengan baik sesuai arahan supervisi dengan berorientasi pada hasil yang dicapai. Sementara itu, ratarata jawaban terendah dengan nilai 3,59 meskipun tergolong baik, responden beranggapan karyawan belum bekerja sesuai dengan kode etik yang telah tertulis. 
Tabel 5 .

Deskripsi Jawaban Responden Variabel Keadilan Organisasi

\begin{tabular}{|c|c|c|c|c|c|c|c|c|}
\hline \multirow{2}{*}{ No } & \multirow{2}{*}{ Daftar Pertanyaan } & \multicolumn{5}{|c|}{ Jawaban } & \multirow{2}{*}{$\begin{array}{l}\text { Rata- } \\
\text { Rata }\end{array}$} & \multirow{2}{*}{ Kriteria } \\
\hline & & SS & $\mathbf{S}$ & CS & TS & STS & & \\
\hline 1. & $\begin{array}{l}\text { Pemberian imbalan yang saya rasakan } \\
\text { sudah adil antar karyawan bank ini. }\end{array}$ & 0 & 0 & 13 & 26 & 31 & 4,26 & $\begin{array}{l}\text { Sangat } \\
\text { Tinggi }\end{array}$ \\
\hline 2. & $\begin{array}{l}\text { Saya dipercaya perusahaan untuk } \\
\text { mengemban tugas sesuai pekerjaan saya } \\
\text { di bank ini. }\end{array}$ & 0 & 2 & 14 & 33 & 21 & 4,04 & Tinggi \\
\hline 3. & Prosedur kerja sudah adil & 0 & 1 & 31 & 29 & 9 & 3,66 & Tinggi \\
\hline 4. & $\begin{array}{l}\text { Bank ini memberikan kesempatan yang } \\
\text { sama bagi karyawan untuk ikut dalam } \\
\text { pengambilan keputusan. }\end{array}$ & 0 & 4 & 26 & 33 & 7 & 3,61 & Tinggi \\
\hline 5. & $\begin{array}{l}\text { Bank ini menunjukkan kepedulian } \\
\text { terhadap karyawan secara adil. }\end{array}$ & 0 & 2 & 19 & 31 & 18 & 3,93 & Tinggi \\
\hline 6. & $\begin{array}{l}\text { Bank ini memberdayakan hak-hak saya } \\
\text { sebagai karyawan secara adil. }\end{array}$ & 0 & 2 & 31 & 25 & 12 & 3,67 & Tinggi \\
\hline & Keadilan Organisa & & & & & & $\mathbf{3 , 8 6}$ & Tinggi \\
\hline
\end{tabular}

Sumber : Data diolah,2019

Tabel 6.

Deskripsi Jawaban Responden Variabel Budaya Organisasi

\begin{tabular}{|c|c|c|c|c|c|c|c|c|}
\hline \multirow{2}{*}{ No } & \multirow{2}{*}{ Daftar Pertanyaan } & \multicolumn{5}{|c|}{ Jawaban } & \multirow{2}{*}{$\begin{array}{c}\text { Rata- } \\
\text { rata }\end{array}$} & \multirow{2}{*}{ Kriteria } \\
\hline & & SS & $\mathbf{S}$ & CS & TS & STS & & \\
\hline 1. & $\begin{array}{l}\text { Karyawan diberikan kesempatan } \\
\text { unuk mengeluarkan pendapat di } \\
\text { bank ini. }\end{array}$ & 0 & 0 & 30 & 28 & 12 & 3,74 & Baik \\
\hline 2. & $\begin{array}{l}\text { Keputusan bank ini diambil } \\
\text { berdasarkan informasi terbaik. }\end{array}$ & 0 & 0 & 15 & 27 & 28 & 4,19 & Baik \\
\hline 3. & $\begin{array}{l}\text { Bank ini secara aktif mendorong } \\
\text { masing-masing unit untuk saling } \\
\text { bekerja sama. }\end{array}$ & 0 & 0 & 32 & 31 & 7 & 3,64 & Baik \\
\hline 4. & $\begin{array}{l}\text { Bank ini mendorong saya unuk } \\
\text { menjalankan tugas dengan } \\
\text { menekankan kepada aktivitas. }\end{array}$ & 0 & 0 & 0 & 30 & 40 & 4,57 & $\begin{array}{l}\text { Sangat } \\
\text { Baik }\end{array}$ \\
\hline 5. & $\begin{array}{l}\text { Saya mudah untuk } \\
\text { mengkoordinsasikan pekerjaan. }\end{array}$ & 0 & 0 & 0 & 45 & 25 & 4,36 & $\begin{array}{l}\text { Sangat } \\
\text { Baik }\end{array}$ \\
\hline 6. & $\begin{array}{l}\text { Bank ini mempunyai Kode Etik } \\
\text { Karyawan secaa tertulis. }\end{array}$ & 0 & 0 & 35 & 29 & 6 & 3,59 & Baik \\
\hline 7. & $\begin{array}{l}\text { Dalam menjalankan tugas saya } \\
\text { selalu berpegang pada prinsip. }\end{array}$ & 0 & 0 & 34 & 28 & 8 & 3,63 & Baik \\
\hline 8. & $\begin{array}{l}\text { Bank ini memiliki kerangka nilai } \\
\text { yang jelas dan konsisten. }\end{array}$ & 0 & 0 & 30 & 29 & 11 & 3,73 & Baik \\
\hline 9. & $\begin{array}{l}\text { Bank ini terus menerus } \\
\text { membandingkan antara kemajuan } \\
\text { dan sasaran. }\end{array}$ & 0 & 0 & 30 & 28 & 12 & 3,74 & Baik \\
\hline 10. & Bank ini memiliki misi yang jelas, & 0 & 0 & 32 & 31 & 7 & 3,64 & Baik \\
\hline 11. & $\begin{array}{l}\text { Saya memahami secara jelas } \\
\text { mengenai nilai-nilai budaya. }\end{array}$ & 0 & 0 & 33 & 27 & 10 & 3,67 & Baik \\
\hline 12. & $\begin{array}{l}\text { Bank ini mampu untuk memenuhi } \\
\text { target jangka pendek. }\end{array}$ & 0 & 0 & 28 & 32 & 10 & 3,74 & Baik \\
\hline \multicolumn{7}{|c|}{ Budaya Organisasi } & 3,85 & Baik \\
\hline
\end{tabular}

Sumber : Data diolah,2019 
Tabel 7.

Deskripsi Jawaban Responden Variabel Pemberdayaan Karyawan

\begin{tabular}{|c|c|c|c|c|c|c|c|c|}
\hline \multirow{2}{*}{ No } & \multirow{2}{*}{ Daftar Pertanyaan } & \multicolumn{5}{|c|}{ Jawaban } & \multirow{2}{*}{$\begin{array}{c}\text { Rata- } \\
\text { rata }\end{array}$} & \multirow{2}{*}{ Kriteria } \\
\hline & & SS & $\mathbf{S}$ & CS & TS & STS & & \\
\hline 1. & $\begin{array}{l}\text { Pihak manajemen perlu } \\
\text { memberikan gambaran secara jelas } \\
\text { mengenai tujuan bank ini. }\end{array}$ & 0 & 0 & 28 & 31 & 11 & 3,76 & Baik \\
\hline 2. & \begin{tabular}{llrr} 
Atasan & saya & \multicolumn{2}{c}{ memberikan } \\
kebebasan & kepada & saya & dalam \\
menetapkan & jadwal & atau & waktu \\
kerja. & & &
\end{tabular} & 0 & 0 & 29 & 32 & 9 & 3,71 & Baik \\
\hline 3. & $\begin{array}{l}\text { Atasan saya selalu memberi } \\
\text { dorongan untuk bekerja dengan } \\
\text { semangat. }\end{array}$ & 0 & 0 & 21 & 36 & 13 & 3,89 & Baik \\
\hline 4. & $\begin{array}{l}\text { Pihak manajemen memberikan } \\
\text { otonomi di dalam pekerjaan saya. }\end{array}$ & 0 & 0 & 30 & 27 & 13 & 3,76 & Baik \\
\hline \multicolumn{7}{|c|}{ Pemberdayaan Karyawan } & 3,76 & Baik \\
\hline
\end{tabular}

Tabel 8.

Deskripsi Jawaban Responden Variabel Komitmen Organisasional

\begin{tabular}{|c|c|c|c|c|c|c|c|c|}
\hline \multirow[b]{2}{*}{ No. } & \multirow[b]{2}{*}{ Daftar Pertanyaan } & \multicolumn{5}{|c|}{ Jawaban } & \multirow{2}{*}{$\begin{array}{l}\text { Rata- } \\
\text { rata }\end{array}$} & \multirow[b]{2}{*}{ Kriteria } \\
\hline & & SS & $\mathbf{S}$ & CS & TS & STS & & \\
\hline 1. & $\begin{array}{l}\text { Saya senang menghabiskan waktu } \\
\text { kerja pada bank ini. }\end{array}$ & 0 & 0 & 0 & 31 & 39 & 4,56 & $\begin{array}{l}\text { Sangat } \\
\text { Tinggi }\end{array}$ \\
\hline 2. & $\begin{array}{l}\text { Saya bersedia melakukan apapun } \\
\text { demi kemajuan bank ini. }\end{array}$ & 0 & 0 & 0 & 15 & 55 & 4,79 & $\begin{array}{l}\text { Sangat } \\
\text { Tinggi }\end{array}$ \\
\hline 3. & $\begin{array}{l}\text { Saya bekerja dalam bank ini } \\
\text { merupakan suatu kewajiban. }\end{array}$ & 0 & 3 & 32 & 28 & 7 & 3,56 & Tinggi \\
\hline 4. & $\begin{array}{l}\text { Saya tidak akan merasa tenang jika } \\
\text { meninggalkan bank ini. }\end{array}$ & 0 & 4 & 31 & 27 & 8 & 3,56 & Tinggi \\
\hline 5. & $\begin{array}{l}\text { Saya sulit mendapatkan pekerjaan } \\
\text { seperti sekarang dengan penghasilan } \\
\text { yang bagus. }\end{array}$ & 0 & 0 & 0 & 25 & 45 & 4,64 & $\begin{array}{l}\text { Sangat } \\
\text { Tinggi }\end{array}$ \\
\hline 6. & $\begin{array}{l}\text { Saya sangat dirugikan jika keluar } \\
\text { dari bank ini. }\end{array}$ & 0 & 1 & 32 & 30 & 7 & 3,61 & Tinggi \\
\hline 7. & $\begin{array}{l}\text { Saya bersedia unuk terlibat dalam } \\
\text { setiap kegiatan bank ini. }\end{array}$ & 1 & 3 & 30 & 25 & 11 & 3,60 & Tinggi \\
\hline 8. & $\begin{array}{l}\text { Bank ini sangat layak mendapatkan } \\
\text { kesetiaan dari saya. }\end{array}$ & 0 & 0 & 0 & 19 & 51 & 4,73 & $\begin{array}{l}\text { Sangat } \\
\text { Tinggi }\end{array}$ \\
\hline 9. & $\begin{array}{l}\text { Saya bangga menjadi bagian dari } \\
\text { bank ini. }\end{array}$ & 0 & 0 & 0 & 12 & 58 & 4,83 & $\begin{array}{l}\text { Sangat } \\
\text { Tinggi }\end{array}$ \\
\hline \multicolumn{7}{|c|}{ Komitmen Organisasional } & 4,21 & $\begin{array}{l}\text { Sangat } \\
\text { Tinggi }\end{array}$ \\
\hline
\end{tabular}

Sumber : Data diolah,2019

Pemberdayaan Karyawan yang baik dengan nilai rata-rata 3,89, dapat diartikan bahwa karyawan selalu mendapat dorongan untuk bekerja dengan semangat, hal ini akan membuat karyawan merasa betah bertahan di organisasi tersebut. Pemberdayaan karyawan dapat dilihat dari karyawan dapat mempengaruhi hasil pekerjaan rekan kerja yang lain, pekerjaan sesuai dengan keinginan karyawan, karyawan memiliki kesempatan yang cukup besar dalam 
melakukan pekerjaan, karyawan percaya diri dengan kemampuan yang dimiliki. Sementara itu, rata-rata jawaban terendah 3,71 hal ini tergolong baik tetapi responden beranggapan bahwa karyawan belum mendapatkan kebebsan dalam menetapkan waktu kerja.

Pada Tabel 9 dapat dilihat bahwa nilai Kolmogorov-Smirnov sebesar 0,931 dan nilai Asymp.Sig. sebesar 0,351. Ini berarti residu dari persamaan regresi dalam penelitian ini terdistribusi secara normal. Nilai Kolmogorov-Smirnov merupakan koefisien yang digunakan untuk mengukur kenormalan distribusi data. Semakin besar nilai Kolmogorov-Smirnov maka akan semakin kecil nilai probabilitasnya (Asymp.Sig), jadi semakin besar nilai Kolmogorov-Smirnov maka semakin tidak normal distribusi data dalam suatu model uji.

Tabel 9.

Hasil Uji Normalitas

\begin{tabular}{llr}
\hline & & Unstandardized Residual \\
\hline $\mathrm{N}$ & & 70 \\
Normal Parameters & Mean $b$ & $0 \mathrm{E}-7$ \\
& Std. Deviation & 1.85979242 \\
Most Extreme Differences & Absolute & .111 \\
& Positive & .068 \\
Kolmogorov-Smirnov $Z$ & Negative & -.111 \\
Asymp. Sig. (2-tailed) & & .931 \\
Sumber $:$ Data diolah,2019 & .351 \\
\hline
\end{tabular}

Tabel 10.

Hasil Uji Multikolinearitas

\begin{tabular}{ccc}
\hline Model & \multicolumn{2}{c}{ Colinearity Statistic } \\
\cline { 2 - 3 } & Tolerance & VIF \\
\hline Keadilan Organisasi $\left(\mathrm{X}_{1}\right)$ & 0,638 & 1,568 \\
Budaya Organisasi $\left(\mathrm{X}_{2}\right)$ & 0,493 & 2,028 \\
Pemberdayaan Karyawan $\left(\mathrm{X}_{3}\right)$ & 0,563 & 1,777 \\
\hline
\end{tabular}

Sumber : Data diolah,2019

Pada Tabel 10. diketahui bahwa nilai tolerance diatas 0,1 dan nilai variance inflation factor (VIF) variabel bebas kurang dari 10, sehingga dapat disimpulkan bahwa tidak ada multikolinearitas antar variabel bebas. Ini berarti tidak ada korelasi atau keterkaitan antar variabel bebas yang diteliti.

Pada Tabel 11. diketahui bahwa nilai Sig. variabel independen berada di atas 0,05 yang bearti tidak terdapat pengaruh antara variabel bebas terhadap absolute residual. Jadi, model yang dibuat tidak mengandung gejala heteroskedastisitas. Sehingga memenuhi syarat homokedastisitas.

Tabel 11.

Hasil Uji Hetroskedastisitas

\begin{tabular}{ccc}
\hline Model & Sig. & Keterangan \\
\hline Keadilan Organisasi $\left(\mathrm{X}_{1}\right)$ & 0,907 & Lolos Uji \\
Budaya Organisasi $\left(\mathrm{X}_{2}\right)$ & 0,543 & Lolos Uji \\
Pemberdayan Karyawan $\left(\mathrm{X}_{3}\right)$ & 0,332 & Lolos Uji \\
\hline
\end{tabular}


Nilai koefisien regresi keadilan organisasi $\left(\mathrm{X}_{1}\right)$ sebesar 0,418 memiliki arti keadilan organisasi berpengaruh positif terhadap komitmen organisasional karyawan pada PT. Bank Tabungan Negara (Persero) Cabang Denpasar, bila nilai keadilan organisasi $\left(\mathrm{X}_{1}\right)$ naik maka nilai dari komitmen organisasional $(\mathrm{Y})$ akan mengalami peningkatan.

Nilai Koefesien regresi budaya organisasi $\left(\mathrm{X}_{2}\right)$ sebesar 0,166 memiliki arti budaya organisasi berpengaruh positif terhadap komitmen organisasional karyawan pada PT. Bank Tabungan Negara (Persero) Cabang Denpasar, bila nilai budaya organisai $\left(\mathrm{X}_{2}\right)$ naik maka nilai dari komitmen organisasional $(\mathrm{Y})$ akan mengalami peningkatan.

Nilai koefisien regresi pemberdayaan karyawan $\left(\mathrm{X}_{3}\right)$ sebesar 0,348 memiliki arti pemberdayaan karyawan berpengaruh positif terhadap komitmen organisasional karyawan pada PT. Bank Tabungan Negara (Persero) Cabang Denpasar, bila nilai pemberdayaan karyawan $\left(\mathrm{X}_{3}\right)$ naik maka nilai dari komitmen organisasional (Y) akan mengalami peningkatan.

Tabel 12.

Hasil Uji Regresi Linier Berganda

\begin{tabular}{|c|c|c|c|c|c|c|}
\hline \multirow[t]{2}{*}{ Mod } & & \multicolumn{2}{|c|}{$\begin{array}{c}\text { Unstandardized } \\
\text { Coefficients }\end{array}$} & \multirow{2}{*}{$\begin{array}{c}\begin{array}{c}\text { Standardized } \\
\text { Coefficients }\end{array} \\
\text { Beta }\end{array}$} & \multirow[t]{2}{*}{$\mathbf{T}$} & \multirow[t]{2}{*}{ Sig. } \\
\hline & & $\boldsymbol{B}$ & Std. Error & & & \\
\hline \multirow{4}{*}{1} & (Constant) & 15,241 & 2,636 & & 5,782 & ,000 \\
\hline & $\begin{array}{l}\text { Keadilan } \\
\text { Organisasi }\end{array}$ & ,418 & ,099 & , 421 & 4,224 &, 000 \\
\hline & Budaya Organisasi & , 166 & ,080 & ,236 & 2,082 &, 041 \\
\hline & $\begin{array}{l}\text { Pemberdayaan } \\
\text { Karyawan }\end{array}$ & ,348 &, 151 & ,244 & 2,299 &, 025 \\
\hline
\end{tabular}

Model analisi linier berganda digunakan untuk mencari koefisien regresi yang akan mengetahui ketergantungan satu variabel terikat dengan satu atau lebih variabel bebas. Hasil analisis regresi linier berganda dapat dilihat pada Tabel 12 . Berdasarkan Tabel 12, maka persamaan regresi linier berganda yang dibentuk adalah sebagai berikut:

$\mathrm{Y}=15,241+0,418 \mathrm{X}_{1}+0,166 \mathrm{X}_{2}+0,348 \mathrm{X}_{3}$

Nilai koefisien regresi keadilan organisasi $\left(\mathrm{X}_{1}\right)$ sebesar 0,418 memiliki arti keadilan organisasi berpengaruh positif terhadap komitmen organisasional karyawan pada PT. Bank Tabungan Negara (Persero) Cabang Denpasar, bila nilai keadilan organisasi $\left(\mathrm{X}_{1}\right)$ naik maka nilai dari komitmen organisasional $(\mathrm{Y})$ akan mengalami peningkatan. Nilai Koefesien regresi budaya organisasi $\left(\mathrm{X}_{2}\right)$ sebesar 0,166 memiliki arti budaya organisasi berpengaruh positif terhadap komitmen organisasional karyawan pada PT. Bank Tabungan Negara (Persero) Cabang Denpasar, bila nilai budaya organisai $\left(\mathrm{X}_{2}\right)$ naik maka nilai dari komitmen organisasional (Y) akan mengalami peningkatan.

Hasil penelitian ini sejalan dengan penelitian yang dilakukan oleh (Diputri \& Rahyuda, 2016) dengan hasil kesimpulan keadilan organisasi berpengaruh 
signifikan terhadap komitmen organisasional. Hasil penelitian yang dikemukakan oleh Pratiwi (2012) dalam penelitiannya menyatakan bahwa ada pengaruh yang searah antara pemberdayaan dengan komitmen organisasional, dengan demikian dapat dikatakan bahwa melalui pemberdayaan karyawan akan mempunyai kontrol secara personal tentang bagaimana melakukan pekerjaan dan memiliki keyakinan akan kemampuan yang dimiliki dengan hasil dalam bentuk komitmen organisasional.

\section{SIMPULAN}

Berdasarkan pembahasan yang telah diuraikan pada bab sebelumnya, maka diperoleh simpulan dimana keadilan organisasi memiliki pengaruh positif dan signifikan terhadap komitmen organisasional. Hal ini menunjukan bahwa semakin karyawan merasakan diberlakukan secara adil dalam organisasi akan meningkatkan komitmen karyawan dalam organisasi. Budaya organisasi memiliki pengaruh positif dan signifikan terhadap komitmen organisasional. Semakin baik budaya yang dimiliki oleh organisasi maka semakin tinggi komitmen karyawan untuk tetap berkomitmen pada perusahaan dan akan berdampak pada peningkatan kinerja PT. BTN Persero Tbk Cabang Denpasar. Pemberdayaan karyawan memiliki pengaruh positif dan signifikan terhadap komitmen organisasional. Hal ini menunjukkan bahwa semakin karyawan diberikan pemberdayaan karyawan akan dapat meningkatkan komitmen karyawan dalam organisasi.

Saran yang diberikan berdasarkan hasil penelitian dan pembahasan adalah sebagai berikut. 1) Organisasi harus memberikan kesempatan yang sama terhadap karyawan dalam pengambilan keputusan. Organisasi juga harus mampu memberdayakan hak-hak karyawan secara adil. 2) Organisasi harus menentukan kode etik secara tertulis yang akan ditanamkan dalam organisasi sehingga mencerminkan visi organisasi, organisasi juga sebaiknya memiliki kerangka nilai yang jelas dan konsisten. 3) Organisasi harus memberikan kebebasan kepada karyawan dalam menetapkan jadwal dan waktu kerja, pihak organisasi juga perlu memberikan gambaran yang jelas mengenai tujuan perusahaan serta melibatkan karyawan dalam proses perencanaan sehingga kemampuan karyawan dapat digunakan sepenuhnya berdasarkan kompentensi yang dimiliki

\section{REFERENSI}

Abadi, M. V. N., \& Chegini, M. G. (2013). Process of Employee Empowerment (Concepts and Dimensions). Kuwait Chapter of Arabian Journal of Business and Management Review, 2(11), 1-20.

Akanbi, P. A., Ofoegbu, O., \& Eugene. (2013). Impact of Perceived Organizational Justice on Organizational Commitment of a Food and Beverage Firm in Nigeria. International Journal of Humanities and Social Science, 3(14), $207-218$.

Anatan, L., \& Ellitan, L. (2007). Manajemen Sumber Daya Manusia dalam Bisnis. Bandung: Alfabeta. 
Ardana, I. K., Mujiati, N. W., \& Utama, I. W. M. (2012). Manajemen Sumber Daya Manusia (Edisi Pert). Yogyakarta: Graha Ilmu.

Astuti, P. D. (2013). Perancangan Sistem Informasi Penjualan Obat Pada Apotek Jati Farma Arjosari. Jurnal Universitas Surakarta, 1(1), 12.

Bakhshi, A., Kumar, K., \& Rani, E. (2009). Organizational Justice Perception As Predictor Of Job Satisfaction And Organization Commitmen. International Journal of Business and Management, 4(9), 1-23.

Brown, R. (2004). Leadership. England: Kogan Page.

Darodjat, T. A. (2015). Konsep-Konsep Dasar Manajemen Personalia- Masa Kini. (Edisi Pert). Bandung: Refika Aditama.

Dehkordi, F. R. S. M., \& Yektayar, M. (2013). Relationship of Organizational Justice and Organizational Commitment of the Staff in General Directorate of Youth and Sports in Chahar Mahal Va Bakhtiari Province. European Journal of Experimental Biology, 3(3), 696-700.

Demirel, Y., \& Yucel, I. (2013). The Effect of Organizational Justice on Organizational Commitment: A Study on Automotive Industry. International Journal of Social Sciences, 2(3), 26-37.

Dessler, G. (2003). Human Resource Management. New Jersey: Prentice Hall.

Dewi, S., \& Suana. (2016). Pengaruh Job Insecurity, Kepuasan Kerja dan Keadilan Organisasi terhadap Komitmen Organisasi Karyawan Kontrak. EJurnal Manajemen Unud, 5(5), 3000 - 3026.

Diputri, N. P. I. P., \& Rahyuda, A. G. (2016). Pengaruh Keadilan Organisasi, Budaya Organisasi, Pemberdayaan Karyawan terhadap Komitmen Organisasi pada LPD Desa Adat Kerobokan. E-Jurnal Manajemen Unud, 5(3), 1457-1485.

Edelstein, S. C., \& Molinski, C. (2012). Corporate Culture And Nutrition Professionals. Journal of Foodservice Business Research, 15(4), 411-418.

Elnaga, A. A., \& Imran, A. (2014). The Impact of Employee Empowerment on Job Satisfaction Theoretical Study. American Journal of Research Communication, 2(1), 13-26.

Farzin, F. R., \& Jirdehi. (2013). Organizational Justice, Employees Trust and Organizational Support. Kuwait Chapter of Arabian Journal of Business and Management Review, 3(2), 74-85. 
Fernandes, C., \& Awamleh, R. (2006). Impact Of Organisational Justice In An Expatriate Work Environment. Journal Management Research, 29(11), 701 $-712$.

Gibson, J. L., Donnelly, J. H., Ivancevich, \& Konopaske, M. (2012). Organizations:Behavior,Structure,Processes. McGraw-Hill.

Haq, M. A., Jindong, Y., Hussain, N., \& Anjum, Z. U. Z. (2014). Factor Affecting Organizational Commitment Among Bank In Pakistan. Journal Business and Management, 16(4), 18-24.

Humborstad, S. I. W., \& Perry, C. (2011). Employee Empowerment, Job Satisfaction, Commitment Organizational An in Dept Emperical Investigation. Chinese Management Studies, 5(3), 325-344.

Ivancevich, K., \& Matteson. (2008). Perilaku dan Manajemen Organisasi. Jakarta: Penerbit Erlangga.

Karim, F., \& Rehman, O. (2012). Impact of Job Satisfaction, Perceived Organizational Justice and Employee Empowerment on Organizational Commitment in Semi Government Organizations of Pakistan. Journal of Business Studies Quarterly, 3(4), 92-104.

Khan, S. (2007). The Key Being a Leader Company Empowerment. Journal for Quality and Participantion, 1(1), 1-12.

Kumar, R., Ramendran, C., \& Yacob, P. (2012). A Study on Turnover Intention in Fast Food Industry: Employees' Fit the Organizational Culture And the Important Of Their Commitment. International Journal Of Academic Research in Business and Social Science, 2(5), 9-42.

Luthans, F. (2006). Perilaku Organisasi. Yogyakarta: Penerbit Andi.

Marissa. (2010). Pengaruh Persepsi tentang Keadilan Organisasi Terhadap Komitmen Organisasi Karyawan PT. Garuda Indonesia (Persero). Universitas Islam Negeri Syarif Hidayatullah.

Nagar, K. (2012). Organizational Commitment and Job Satisfaction among Teachers during Times of Burnout. The Journal for Decision Market, 37(2), $1-20$.

Ogut, E., Sahin, M., \& Demirsel, M. T. (2013). The Relationship Between Perceived Organizational Justice and Cyberloafing: Evidence from a Public Hospital in Turkey. Mediterranean Journal of Social Sciences, 4(10), 226233. 
Ongori, H. (2008). Managing Behind The Scenes: A View Point on Employee Empowerment.

Pratiwi, P. (2012). Pengaruh Budaya Organisasi Dan Pemberdayaan Terhadap Komitmen Organisasional Dalam Meningkatkan Kinerja Aset. Jurnal Administrasi Bisnis, 14(1), 41-52.

Priansa, D. J. (2016). Perencanaan \& Pengembangan SDM (Edisi ke 2). Bandung: Alfabeta.

Ravangard, R., \& Ansarizade, Z. S. and N. (2013). Study Of The Effects Of Perceived Organizational Justice And Its Components On Organizational Commitment Of Administrative And Financial Employees Of Shiraz University Of Medical Sciences General Hospital In 2012. Archives of Pharmacy Pratice, 4(1), 1-20.

Renaud, L. (2012). Impact Of Culture On The Organizational Commitment Of Public-Sector Employees In Haiti. International Business \& Economics Research Journa, 11(3), 331-342.

Robbins, S. P., \& Judge, T. A. (2008). Perilaku Organisasi. Jakarta: Salemba Empat.

Schuler, R. S., \& Jackson, S. E. (1997). Manajemen Sumber Daya Manusia Menghadapi abad ke 21. Jakarta: Erlangga.

Shurbagi, A. M. A., \& Zahari, I. (2013). The Relationship between Transformational Leadership and Organizational Culture in National Oil Corporation of Libya. International Journal of Business Administration, $4(4), 1-20$.

Sidartha, N., \& Margaretha, M. (2011). Dampak Komitmen Organisasi Dan Kepuasan Kerja Terhadap Turnover Intention: Studi Empiris Pada Karyawan Bagian Operator Di Salah Satu Perusahaan Garment Di Cimahi. Jurnal Manajemen, 10(2), 1-20.

Suhermin. (2012). Pemberdayaan Kerja Profesional Sebagai Mediasi Dukungan Organisasi Dan Pertukaran Pemimpin Anggota (LMX) Terhadap Komitmen Organisasi. Jurnal Ekonomi Dan Keuangan, 16(2), 209-229.

Sutrisna, I. W. W., \& Rahyuda, A. G. (2014). Pengaruh Keadilan Distributif, Prosedural, Dan Interaksional Terhadap Kepuasan Kerja Dan Komitmen Organisasi Pada Paramedis Di Rumah Sakit Tk II Udayana Denpasar. EJurnal Manajemen Universitas Udayana, 3(9), 2489 - 2509. 
Indra Dwi Isnanto, Pengaruh Keadilan Organisasi...

Tintri, D. (2005). Pengaruh Disiplin Kerja Terhadap Produktivitas Kerja Karyawan pada PT. food Station Tjipinang Jaya. Jurnal Manajemen Publik Dan Bisnis, 1(1), 1-20.

Utami. (2009). Hubungan Antara Aktivitas Fisik, Asupan Zat Gizi Makro, Asupan Serat dengan Obesitas PNS di Kepolisian Resor Kota Besar Banda Aceh. Univeristas Indonesia.

Wirawan. (2007). Budaya dan Iklim Organisasi. Jakarta: Salemba Empat.

Yavuz, M. (2010). The Effects of Teachers' Perception of Organizational Justice and Culture on Organizational Commitment. African Journal of Business Management, 4(5), 695-701.

Yukl, G. A. (2006). Kepemimpinan dalam Organisasi. Jakarta: PT. Indeks. 